\title{
EARTHQUAKES, LANDSLIDES, AND LARGE DAMS IN NEW ZEALAND
}

\author{
John Adams*
}

\section{ABSTRACT:}

Earthquake-triggered landslides pose two indirect hazards to large dams: dam collapse due to upstream dam failure, and reservoir infilling by earthquake-generated sediment. The Buller earthquake generated sediment equivalent to 800 years of normal erosion in the Karamea catchment. The effects of this and other historic earthquakes in New Zealand indicate the magnitude of the hazard to present dams and may aid in the safe design of future dams.

\section{INTRODUCTION:}

Very few regions of New zealand are totally free of earthquake risk. There is potential risk even in those parts of the axial ranges (e.g. central southern Alps, Raukumara Ranges) that have not been damaged by an earthquake during the short historic record (Adams ${ }^{1}, 1980$, Nishenko and McCann ${ }^{9}, 1981$ ).

In addition to the direct effects which earthquake shaking has on dam foundations and stability, which are engineering problems well tackled by others, there are two indirect risks to New Zealand's present large dams to be considered in the siting and design of future dams. Firstly, dams may breach or collapse from the deluge caused by the upstream failure of a natural or artificial dam. Secondly, the reservoirs may be rapidly infilled by the sediment released by the earthquake, resulting in drastically reduced water storage capacity.

\section{DAM COLLAPSE:}

A major effect of earthquakes in the mountainous parts of New Zealand is the catastrophic sliding of unstable hillslopes from the mountain crests into the valleys as landslides and rock avalanches. Some and because they come to rest on the valley floor they impound large lakes such as Lakes Waikaremoana, Chalice, Matiri and Stanley and at least 30 smaller lakes. Waikaremoana and Chalice are more than 2000 years old, but Matiri is a few hundred years old and stanley was formed during the 1929 Buller earthquake (Adams ${ }^{3}, 1981$ ). Though rapidly formed, the stability of these lakes is shown by their survival for tens or thousands of years.

Other landslides that once dammed rivers are less permanent, however, and several have been destroyed in historic times, though fortunately without catastrophic effects. For example, the Mokihinui River was dammed in its gorge by a wedge-shaped landslide $100 \mathrm{~m}$ wide composed of large boulders that fell during the same earthquake that formed Lake Stanley. Seventeen days later part

*Visiting Fellow, Earth Physics Branch

Energy, Mines \& Resources, Ottawa, Canada of this natural dam was washed out, the lake was lowered by $8 \mathrm{~m}$, and the resultant waters flooded Seddonville (Henderson 7, 1937, p. 122).

Lake Ngatapa (also known as Te Hoe Lake) was formed during the 1931 Hawkes Bay earthquake when a landslide dammed a tributary of the Mohaka River. When the lake was washed out during a major flood in 1938, the lake waters (volume about $5 \times 10^{6} \mathrm{~m}^{3}$ ) represented only $5 \%$ of the flood discharge of the Mohaka (Grant ${ }^{6}, 1939$, p. 59), and caused little additional damage.

A landslide, triggered by the Inangahua earthquake, dammed the Buller River in 1968 (Johnston 8 1974). The landslide contained $4.3 \times 10^{6} \mathrm{~m}^{3}$ of weathered rock and formed a dam $12 \mathrm{~m}$ high that ponded the river for a length of $6 \mathrm{~km}$. When the dam failed suddenly 21 hours after the earthquake, approximately $1.5 \times 10^{6} \mathrm{~m}^{3}$ of water was released and moved downstream at about $5.4 \mathrm{~m} \mathrm{sec}^{-1}$ (Sutherlandl2, 1969).

In certain circumstances, the failure of a landslide dam located immediately upstream from another dam could release a "wave of water" that might seriously exceed the designed spillway discharge of the downstream dam and so threaten the stability of this dam or its abutments. Related hazards would be the direct fall of a landslide into a reservoir (cf. the vaiont disaster, Italy; Slingerland and Voight ${ }^{11}$ 1979), and the inundation of generators at a power dam by a downstream landslidedammed lake, a hazard that has been assessed for the Kresmasta Power house in Greece (Wong and Gilmore ${ }^{13}, 1979$ ).

\section{DAM SILATION :}

Even in the absence of catastrophic floods from temporarily-ponded waters, earthquake-generated landslides could threaten the normal running and economic operation of many power dams.

In mountainous areas, earthquakes have caused landslides which delivered vast amounts of sediment from the hillslopes into the river valleys leaving behind bare, easily-eroded scars. The amount of erosion caused by three earthquakes in the northeast South Island of New Zealand has been estimated from the number and size of the landslides visible 
on air photographs (Table 1). The figures are approximate because 1) not all landslides were visible on the photographs, and some of those visible might not have been caused by the earthquakes, and 2) an empirical relationship between landslide area and volume had to be assumed (see Adams $^{2} 1980, p .65$ ). Scars formed by the Buller earthquake are still visible on air photographs taken decades after the earthquake. Their visibility shows that the landslides scars re-vegetate slowly and continue to erode long after their formation.

Much of the landslide material delivered to the rivers is soil and weathered rock that is rapidly broken down in the rivers and carried as suspended load to the sea, the rivers carrying a higher concentration of suspended sediment after an earthquake than is usual. A crude analysis of suspended sediment data at Te Kuha on the Buller River before and after the Buller earthquake showed that (in addition to the normal load) $160 \times 10^{9} \mathrm{~kg}$ of earthquakegenerated sediment was carried during the eight years after the earthquake, half of it in the first 19 months (Adams2. $1980, p .70)$. For the Madang earthquake in New Guinea, a similar analysis (Pain and Bowler 10 1973), indicated that half the $\sim 50 \times 10^{9} \mathrm{~kg}$ that slipped reached the sea in the first six months.

Bapat $^{4}$ (1980) has given the downstream sediment effects of landslides in the headwaters of the Sutlej River, India, caused by a magnitude 6.5 earthquake in January 1975. Sediment carried into the Bhakra dam reservoir increased from $19 \times 10^{9} \mathrm{~kg}$ in 1974 to $39 \times 10^{9} \mathrm{~kg}$ in 1975, even though the affected area was $200 \mathrm{~km}$ upstream and only a small part of the total catchment. Based on the recurrence interval of the earthquakes, Bapat estimated that the earthquake-caused sedimentation could shorten the life of the reservoir by 15 to $35 \%$.

After the Inangahua earthquake, the sediment load in the rivers was half again as large as the volume of the landslides, perhaps partly due to erosion of the bare landslide scars. Although the earthquake affected only a small part ( 15\%) of the large Buller catch ment, over the eight year period after the earthquake, the additional sediment was three times the normal river load at Te Kuha.

The volume of landslides during the 1929 Buller earthquake was far larger than during the Inangahua earthquake. epicentre was just south of the Karamea catchment, and of the total $2.3 \times 10^{12} \mathrm{~kg}$ that slid, nearly half ( $1 \times 10^{12} \mathrm{~kg}$; Adams, unpublished) slipped in the Karamea catchment alone. This amount should be compared with the usual sediment load of the Karamea River. Crude estimates of the load indicate erosion rates of $0.3 \times 10^{6}$ $\mathrm{kg} \mathrm{km-2} \mathrm{yr}^{-1}$ for the Karamea catchment (Adams2, 1980, table 4). However because the adjoining and topographically-similar Mokihinui catchment is eroding at $1.6 \times 10^{6}$ $\mathrm{kg} \mathrm{km} \mathrm{km}^{-2} \mathrm{yr}^{-1}$, a higher erosion rate of $1 \times 10^{6} \mathrm{~kg} \mathrm{~km}^{-2} \mathrm{yr}^{-1}$ is not unreasonable for the Karamea catchment. The sediment load from the $1160 \mathrm{~km}^{2}$ Karamea catchment is at least $0.3 \times 10^{9} \mathrm{~kg} \mathrm{yr}^{-1}$ and could be $1.2 \times 10^{9} \mathrm{~kg} \mathrm{y^{-1 }}$. Therefore the $1 \mathrm{x} 1012 \mathrm{~kg}$ of sediment supplied by the Buller earthquake was equivalent to more than 800 years of "normal" erosion.

Suppose a dam were to be built on the Karamea River in the narrow gorge nearest the sea. If it were $150 \mathrm{~m}$ high it could impound about $250 \times 10^{6} \mathrm{~m}^{3}$ of water. If the dam had been built before the Buller earthquake, it would have been completely filled with sediment in the following 2 to 5 years. The filling assumes a density of $1250 \mathrm{~kg} \mathrm{~m}^{-3}$ for the deposited sediment and assumes that one third of the sediment remains trapped in the headwaters and a second third passes the dam completely. Even if the dam were not completely filled, the amount of active storage would be drastically reduced.

\section{DISCUSSION AND CONCLUSIONS:}

There is questionable value in spending a good deal of effort to determine the usual sediment load of a river accurately, and on this basis designing a dam and reservoir with sufficient sediment storage capacity for (say) a 800-year life, if soon after completion the reservoir is completely filled by "rare" earthquake-caused erosion.

It is not known just when earthquakes the size of the Inangahua and Buller earthquakes will re-occur in the Karamea area, as geomorphic studies of faulted river terraces indicate that the region might be an order of magnitude less seismic than the historic record indicates (Berryman 5 , 1980). In addition the energy released by the Buller earthquake may have lowered the short-term risk in the area. However, two other New Zealand regions are believed to be especially at risk: the central Southern Alps, where there is evidence of past large earthquakes on the Alpine Fault even though none have occurred since European settlement (Adams ${ }^{1}, 1980$ ); and the Raukumara Ranges, North Island, where the rocks are weak and prone to landsliding and where there have been no large historic earthquakes despite large earthquakes to the south (Nishenko and McCann ${ }^{9}$, 1981).

If the hazards described in this paper are perceived as risks, then the design of dam crests and downstream walls to permit safe overtopping, the protection of abutments, and the provision of bottom-opening sluiceways to flush accumulated sediment would mitigate the damage that might be caused to dams by earthquake-caused landslides.

\section{REFERENCES :}

1. Adams, J. (1980). "Paleoseismicity of the Alpine Fault seismic gap, New Zealand", Geology 8, 72-76. 
2. Adams, J. (1980). "Contemporary uplift and erosion of the Southern Alps; New Zealand", Geological Society of America, Bulletin Part 2, 91, 1-114.

3. Adams, J. (1981). "Earthquakedammed lakes in New Zealand", Geology (in press).

4. Bapat, A. (1980). "Silting of reservoirs due to earthquakes", Indian Society of Earthquake Technology, 17, 29-32.

5. Berryman, K. (1980). "Late Quaternary movement on white Creek Fault, South Island, New Zealand", New Zealand Journal of Geology and Geophysics, 23, 93-101.

6. Grant, A.P. (1939). "Hawke's Bay flood, 23rd-25th April 1938", New Zealand Institution of Engineers, Proceedings, 25, 55-64.

7. Henderson, J. (1937). "West Nelson earthquake of 1929", New Zealand Journal of Science and Technology, 19, 66-144.

8. Johnston, M.R. (1974). "Major landslides in the Upper Buller Gorge, South-west Nelson", New Zealand Institution of Engineers, Transactions, $1,239-244$

9. Nishenko, S.P.; and McCann, W.R. (1981). "Seismic potential for the world's major plate boundaries", Proceedings, Maurice Ewing Symposium on Earthquake Prediction, American Geophysical Union (in press).

10. Pain, C.F., and Bowler, J.M. (1973). "Denudation following the November 1970 earthquake at Madang, Papua New Guinea", Zeitschrift fur

Geomorphologie, Suppl. Bd. 18, 92-104 .
11. Slingerland, R.L., and Voight, B. (1979). "Occurrences, properties, and predictive models of landslidegenerated water waves" Chapter 9 in Voight, B. (ed.), "Rockslides and avalanches, 2" Developments in Geotechnical Engineering 14B, Elsevier, Amsterdam, 317-397.

12: Sutherland, A.J. (1969). "Some hydrological aspects of the Inangahua earthquake", New Zealand Journal of Science, 12, 476-496.

13. Wong, I.H., and Gilmore, J.J. (1979). "Static stability of Kastraki Reservoir slope", Proceedings 20 th U.S. Symposium on Rock Mechanics, 337-343.

\section{TABLE 1}

Amount of erosion caused by three earthquakes in New Zealand (Adams ${ }^{2} 1980$ )

\begin{tabular}{|lccc|}
\hline Earthquake & Arthur's Pass & Buller & Inangahua \\
\hline Date & 9 Mar 1929 & 17 Jun 1929 & 23 May 1968 \\
Magnitude & 6.9 & 7.7 & 7.1 \\
$\begin{array}{l}\text { Centre of landslide } \\
\text { region }\end{array}$ & 42.8 & 41.45 & \\
lat. (OS) & 171.85 & 172.4 & 17.83 \\
long. (OE) & $106 *$ & 1300 & 94 \\
$\begin{array}{l}\text { Mass of landslides } \\
\text { (109 } \mathrm{kg})\end{array}$ & & & \\
\hline
\end{tabular}

*Does not include Falling Mountain landslide of $117 \times 10^{9} \mathrm{~kg}$

(Whitehouse, pers. commun., 1981). 